\title{
Towards Improved Circular Economy and Resource Security in South Korea
}

\author{
Kyounga Lee ${ }^{1}$ and Jongmun Cha ${ }^{2, * \mathbb{D}}$ \\ 1 Faculty of Law, Saarland University, 66123 Saarbrücken, Germany; leekyounga@gmail.com \\ 2 Department of Energy and Mineral Resources Engineering, Dong-A University, Busan 49315, Korea \\ * Correspondence: jmcha@dau.ac.kr
}

check for updates

Citation: Lee, K.; Cha, J. Towards Improved Circular Economy and Resource Security in South Korea. Sustainability 2021, 13, 17. https: / /dx. doi.org/10.3390/su13010017

Received: 6 November 2020 Accepted: 21 December 2020 Published: 22 December 2020

Publisher's Note: MDPI stays neutral with regard to jurisdictional claims in published maps and institutional affiliations.

Copyright: () 2020 by the authors. Licensee MDPI, Basel, Switzerland. This article is an open access article distributed under the terms and conditions of the Creative Commons Attribution (CC BY) license (https: / / creativecommons.org/ licenses/by/4.0/).

\begin{abstract}
This study explores the importance of critical raw materials and minerals by analyzing the Republic of Korea's recent circular economy and resource security policy. Raw materials and rare metals are becoming increasingly significant to the Korean economy because the country is currently shifting away from fossil fuels and nuclear power towards renewable energy resources as well as transforming its industries towards decarbonization, digitization, and automation. Korea is a resource-poor country and is heavily dependent on imported minerals and rare earths, which are essential for its economy and new industry. Responding to these challenges and concerns, Korea is moving towards a sustainable circular economy and achieving greater resource security. Despite certain limitations, this transition would ultimately contribute in preparing Korea for current and future challenges in the areas of critical raw materials and minerals.
\end{abstract}

Keywords: circular economy; critical raw material; critical mineral; resource security

\section{Introduction}

Today, we face global challenges concerning climate change, resource scarcity, the security of raw materials, population growth, and increasing consumption, all of which are burdening the sustainable development of the Earth [1]. Overcoming this sustainability crisis will require a paradigm shift to maintain economic prosperity and societal stability for future generations. In particular, raw materials and rare metals are becoming increasingly significant to our economies, their global demand is growing, and global competition for accessing critical minerals and metals is becoming stronger. Moreover, due to technological innovation and the emergence of new technologies, countries are transforming their industries towards decarbonization, digitization, and automation. As geological deposits and production are geographically concentrated in a very small number of countries, securing reliable, sustainable, and undistorted access to them is a matter of growing concern for highly dependent countries, which rely on the imports of critical raw materials and minerals [2-4].

The Republic of Korea (Korea) is a resource-poor country and one of the largest energy consumers worldwide [5]. Due to the lack of domestic raw materials, Korea is heavily dependent on imported critical raw materials, which are essential for its main industries, such as the production of steel, semiconductors, automobiles, and ships [6]. Korea is currently in a state of transition from fossil fuels and nuclear power towards renewable energy sources. The government announced the "Renewable Energy 3020 Plan", which aims to increase the share of renewable energy in the energy sector by $20 \%$ by $2030[7,8]$. Furthermore, Korea experiences industry transformation [9] in response to technological developments such as autonomous driving, 3D printing, drones, and renewable energy, which are often described as Industry 4.0 (or the 4th industrial revolution) [10].

In response to these challenges and concerns, Korea is moving towards a sustainable circular economy, thereby achieving greater resource security. Circular economy and 
resource security have become Korea's environmental and resource policy priorities. Specifically, Korea enacted the Framework Act on Resource Circulation (FARC), which came into effect on 1 January 2018. To prescribe specific requirements delegated by the FARC and the necessary conditions to enforce it, the FARC enforcement decree and rule were enacted. Subsequently, the First Master Plan on Resource Circulation (Resource Circulation Plan) was established for the transition towards a circular economy under Article 11 of the FARC. Recently, Korea published the Master Plan on Resource Development (Resource Development Plan).

The several problems to be resolved include the major challenges for Korea in the raw materials and minerals sector, roles of critical raw materials or critical minerals in Korea's circular economy and resource security policy, and if Korea's recent transition towards circular economy and resource security can contribute in solving the current challenges. To resolve these problems, this study employs an interdisciplinary approach from legal and practical perspectives and explores the importance of critical raw materials and minerals through an analysis of Korea's circular economy and resource security policy. The remainder of this paper is presented as follows. We provide an overview of the current status of Korea's mineral resources and challenges as well as the classification of critical minerals or critical mineral resources. We then analyze the recent developments in Korea's circular economy law and policy, including the First Master Plan on Resources Circulation and the current direction of Korea's resource policy and strategy described in the Master Plan on Resources Development Plan. We also present a short assessment of renewable energy and critical raw materials to show the interdependence between circular economy and resource security. In conclusion, our study discusses important concerns and future considerations.

\section{Overview of Current Status of Korea's Critical Mineral Resources and Challenges}

\subsection{Overview}

The Korean peninsula is geographically divided into south and north, and it is the storm center of Asia, surrounded by the conflicts of interests between China, Japan, Russia, and the Democratic People's Republic of Korea (North Korea). Korea's major challenges originate from China and Japan, being sandwiched between them. China has been restricting its raw materials and rare earths exports and aggressively expanding resource investments overseas. Japan, which is a leader in metal production and processing, has restricted its raw material exports to Korea. Korea's manufacturing industry suffers from a lack of raw material resources and a weak supporting industry [11,12]. Most primary raw materials are imported from China and refinery materials from Japan to supply its industries and markets [11].

Korea has deposits of some nonmetallic minerals such as feldspar, limestone, siliceous earth, quartz sand, sulfur, serpentine, talc, and zeolite; however, it has limited domestic deposits of rare metals such as titanium, molybdenum, tungsten, tin, vanadium, and lithium $[11,13]$. In contrast, it is established that North Korea possesses abundant underground resources including coal, copper, fluorspar, gold, graphite, iron ore, lead, magnesium, rare earth elements, silver, tungsten, and zinc. However, North Korea has never made its public reserves of natural resources or actual production volumes official [11,14].

Because of Korea's heavy dependence on raw material imports and vulnerability to the changes in external economic circumstances, Korea has made efforts to overcome this by establishing comprehensive resource strategies, including securing overseas raw material supplies, stockpiling reserves, technological innovation, and developing a recycling industry [11]. Moreover, Korea explores the possibility of close resource cooperation and participation in investing and developing North Korea's natural resources [14].

The current dispute between Korea and Japan and the rare earth crisis in 2010 demonstrate that the world's dominant producers and suppliers, which hold large global market shares in raw materials or rare earth elements, could use their dominance on these materials as a political weapon to solve unrelated disputes [2]. China is the world's largest producer, 
consumer, and exporter of rare earths, controlling $90 \%$ of the global supply base $[15,16]$. Owing to a territorial dispute between China and Japan, China disrupted the supply of rare earths to Japan. Accordingly, together with the European Union (EU) and the United States, Japan requested consultations under the World Trade Organization (WTO) Dispute Settlement Understanding with China over export restrictions on rare earths [17].

The recent dispute between Korea and Japan resembled the rare earths crisis in 2010. Japan restricted the exports of three kinds of critical materials (resists, hydrogen fluoride, and fluorinated polyamide) used in Korea's high-tech industry, such as semiconductors and digital displays, by citing national security concerns regarding the mishandling of sensitive exports [18]. Japan has a 70\% to $90 \%$ global market share for these materials, and the dependence of Korean companies on Japan is $94 \%$ in polyimide, $92 \%$ in resist, and $44 \%$ in etching gas [19], rendering it difficult for Korean tech giants, including Samsung Electronics, SK Hynix, and LG Display to find alternatives [20]. Moreover, Japan removed Korea from the white list of countries that receive preferential treatment on requirements for importing sensitive Japanese goods. The new measure will lead to a stricter approval process that could require Korean exporters to take extra administrative procedures to secure export licenses. Consequently, tensions between the two countries were growing, and they could jeopardize their long-standing trade partnership. In response to Japan's export restrictions, Korea requested consultations with Japan under the WTO Dispute Settlement Understanding with respect to Japan's export restrictions [12,21].

\subsection{Classification of Critical Minerals or Critical Raw Materials}

The classification of raw materials or mineral resources can be different for countries with different levels of economic development and natural resource endowment. Determining which minerals or metals are critical depends on the nature of the country's industry, national interests and security concerns, technology, and market changes. A standardized definition of criticality is absent, which is a relative concept that explores the question of "critical to whom?" [3,22].

Korea, the EU, the United States, Australia, and Japan recognize the economic importance of critical raw materials and minerals and adopt different resource strategies. They undertake a more strategic approach to ensure the security of supply of these critical raw materials and minerals by making a list of critical raw materials or critical minerals, as shown in Tables 1 and 2. The EU publishes a list of critical raw materials every three years (14 materials in 2011, 20 materials in 2014, and 27 materials in 2017). It classifies 30 raw materials as critical in 2020 that have significant economic importance for the European economy, high supply risk due to heavy import dependence, high concentration levels in particular countries, and the lack of substitutes [23]. The United States identifies 35 critical minerals that are essential to the economy and national security of the country, which are subject to risk of supply disruption and serve an essential function in the manufacturing of a product $[24,25]$. Australia is a resource-rich country, a relatively small consumer of minerals, and one of the major exporters of minerals; it identifies 24 critical minerals because they are deemed critical by many countries against Australia's known geological endowment [26]. Japan identifies 31 critical minerals [26]. 
Table 1. List of Rare Metals/Critical Raw Materials/Critical Minerals.

\begin{tabular}{|c|c|c|c|c|}
\hline Sout & )) & 8) & (24) & 8) \\
\hline $\begin{array}{r}\text { Antin } \\
\text { Bariu } \\
\text { Bisn } \\
\text { Cadm } \\
\text { Chrome, } \\
\text { Germar } \\
\text { Rare E } \\
\text { Indi } \\
\text { Magnesi } \\
\text { Molyb } \\
\text { Niobi } \\
\text { Gr } \\
\text { Phosph } \\
\text { Seler } \\
\text { Stronti } \\
\text { Telluri } \\
\text { Titaniun } \\
\text { Vanadi }\end{array}$ & $\begin{array}{c}\text { Antimony, Baryte, } \\
\text { Bauxite, Beryllium, } \\
\text { Bismuth Borate, Cobalt, } \\
\text { Coking Coal, Fluorspar, } \\
\text { Gallium, Germanium, } \\
\text { Hafnium, Heavy Rare } \\
\text { Earth Elements, Indium, } \\
\text { Light Rare Earth } \\
\text { Elements, Lithium, } \\
\text { Magnesium, Natural } \\
\text { Graphite, Natural } \\
\text { Rubber, Niobium, } \\
\text { Platinum Group Metals, } \\
\text { Phosphate rock, } \\
\text { Phosphorus, Scandium, } \\
\text { Strontium, } \\
\text { Silicon metal, Tantalum, } \\
\text { Titanium, Tungsten, } \\
\text { Vanadium }\end{array}$ & $\begin{array}{l}\text { Aluminum (bauxite), } \\
\text { Antimony, Arsenic, Barite, } \\
\text { Beryllium, Bismuth, } \\
\text { Cesium, Chromium, } \\
\text { Cobalt, Fluorspar, } \\
\text { Gallium, Germanium, } \\
\text { Graphite (natural), } \\
\text { Hafnium, Helium, } \\
\text { Indium, Lithium, } \\
\text { Magnesium, Manganese, } \\
\text { Niobium, Platinum group } \\
\text { metals, Potash, Rare earth } \\
\text { elements group, Rhenium, } \\
\text { Rubidium, Scandium, } \\
\text { Strontium, Tantalum, } \\
\text { Tellurium, Tin, Titanium, } \\
\text { Tungsten, Uranium, } \\
\text { Vanadium, Zirconium }\end{array}$ & $\begin{array}{c}\text { Antimony, } \\
\text { Beryllium, Bismuth, } \\
\text { Chromium, Cobalt, } \\
\text { Gallium, } \\
\text { Germanium, } \\
\text { Graphite, Hafnium, } \\
\text { Helium, Indium, } \\
\text { Lithium, } \\
\text { Magnesium, } \\
\text { Manganese, } \\
\text { Niobium, Platinum } \\
\text { group elements, } \\
\text { REE, Rhenium, } \\
\text { Scandium, } \\
\text { Tantalum, Titanium, } \\
\text { Tungsten, } \\
\text { Vanadium, } \\
\text { Zirconium }\end{array}$ & $\begin{array}{c}\text { Antimony, } \\
\text { Beryllium, Carbon, } \\
\text { Chrome, Cobalt, } \\
\text { Copper, Fluorine, } \\
\text { Gallium, } \\
\text { Germanium, Gold, } \\
\text { Indium, Lead, } \\
\text { Lithium, } \\
\text { Magnesium, } \\
\text { Manganese, } \\
\text { Molybdenum, } \\
\text { Nickel, Niobium, } \\
\text { PGM, Phosphorus, } \\
\text { REE, Rhenium, } \\
\text { Silver, Strontium, } \\
\text { Tantalum, Tin, } \\
\text { Titanium, Tungsten, } \\
\text { Vanadium, Zinc, } \\
\text { Zirconium }\end{array}$ \\
\hline
\end{tabular}

Table 2. Table of Rare Metals in South Korea.

\begin{tabular}{|c|c|c|c|c|c|c|c|c|}
\hline & $\begin{array}{c}\text { Rare } \\
\text { Metals }\end{array}$ & EU & US & Australia & Japan & Leading Producer(s) & $\begin{array}{l}\text { Korea's } \\
\text { Import } \\
\text { Reliance }\end{array}$ & Major Sources (2019) \\
\hline 1 & Antimony & $\sqrt{ }$ & $\sqrt{ }$ & $\sqrt{ }$ & $\sqrt{ }$ & China & 100 & China, Vietnam, Japan \\
\hline 2 & Arsenic & & $\sqrt{ }$ & & & China & NA & China, Germany, Japan \\
\hline 3 & Barium & $\sqrt{ }$ & $\sqrt{ }$ & & & China, India & Almost 100 & $\begin{array}{c}\text { Japan, China, U.S., } \\
\text { Germany }\end{array}$ \\
\hline 4 & Beryllium & $\sqrt{ }$ & $\sqrt{ }$ & $\sqrt{ }$ & $\sqrt{ }$ & U.S. & NA & $\begin{array}{l}\text { Japan, U.S., } \\
\text { Netherlands }\end{array}$ \\
\hline 5 & Bismuth & $\sqrt{ }$ & $\sqrt{ }$ & $\sqrt{ }$ & & China & NA & Japan, China, Taiwan \\
\hline 6 & Boron & $\sqrt{ }$ & & & & $\begin{array}{c}\text { Turkey, Kazakhstan, } \\
\text { Chile }\end{array}$ & 100 & $\begin{array}{l}\text { U.S., Turkey, China, } \\
\text { Japan }\end{array}$ \\
\hline 7 & Cadmium & & & & & $\begin{array}{c}\text { China, Korea, Japan, } \\
\text { Mexico, Canada, } \\
\text { Kazakhstan }\end{array}$ & NA & U.S., Germany, Japan \\
\hline 8 & Cesium & & $\sqrt{ }$ & & & Canada & 100 & NA \\
\hline 9 & Chromium & & $\sqrt{ }$ & $\sqrt{ }$ & $\sqrt{ }$ & $\begin{array}{l}\text { South Africa, } \\
\text { Kazakhstan }\end{array}$ & 100 & China, U.S., Japan \\
\hline 10 & Cobalt & $\sqrt{ }$ & $\sqrt{ }$ & $\sqrt{ }$ & $\sqrt{ }$ & DRC & 100 & $\begin{array}{c}\text { China, Japan, DRC, } \\
\text { Australia }\end{array}$ \\
\hline 11 & Gallium & $\sqrt{ }$ & $\sqrt{ }$ & $\sqrt{ }$ & $\sqrt{ }$ & China & 100 & China, U.S., Japan \\
\hline 12 & Germanium & $\sqrt{ }$ & $\sqrt{ }$ & $\sqrt{ }$ & $\sqrt{ }$ & China & NA & China, Canada, U.S. \\
\hline 13 & Hafnium & $\sqrt{ }$ & $\sqrt{ }$ & $\sqrt{ }$ & & U.S. & 100 & U.S., Japan, China \\
\hline 14 & Indium & $\sqrt{ }$ & $\sqrt{ }$ & $\sqrt{ }$ & $\sqrt{ }$ & China, South Korea & NA & $\begin{array}{c}\text { China, Japan, Taiwan, } \\
\text { U.S. }\end{array}$ \\
\hline 15 & Lithium & $\sqrt{ }$ & $\sqrt{ }$ & $\sqrt{ }$ & $\sqrt{ }$ & $\begin{array}{l}\text { Australia, Chile, } \\
\text { China, Argentina }\end{array}$ & 100 & Chile, China, Argentina \\
\hline 16 & Magnesium & $\sqrt{ }$ & $\sqrt{ }$ & $\sqrt{ }$ & $\sqrt{ }$ & China & 100 & China, Japan, Russia \\
\hline 17 & Manganese & & $\sqrt{ }$ & $\sqrt{ }$ & $\sqrt{ }$ & $\begin{array}{c}\text { South Africa, } \\
\text { Australia, Gabon, } \\
\text { China }\end{array}$ & 100 & $\begin{array}{c}\text { Australia, South Africa, } \\
\text { Japan }\end{array}$ \\
\hline
\end{tabular}


Table 2. Cont.

\begin{tabular}{|c|c|c|c|c|c|c|c|c|}
\hline & $\begin{array}{c}\text { Rare } \\
\text { Metals }\end{array}$ & EU & US & Australia & Japan & Leading Producer(s) & $\begin{array}{l}\text { Korea's } \\
\text { Import } \\
\text { Reliance }\end{array}$ & Major Sources (2019) \\
\hline 18 & Molybdenum & & & & $\sqrt{ }$ & $\begin{array}{l}\text { China, Chile, U.S., } \\
\text { Peru, Mexico, Russia }\end{array}$ & Almost 100 & $\begin{array}{l}\text { Chile, Mexico, U.S., } \\
\text { China }\end{array}$ \\
\hline 19 & Nickel & & & & $\sqrt{ }$ & $\begin{array}{c}\text { Philippines, Canada, } \\
\text { Russia, Australia, New } \\
\text { Caledonia }\end{array}$ & 100 & $\begin{array}{l}\text { New Caledonia, Japan, } \\
\text { Finland }\end{array}$ \\
\hline 20 & Niobium & $\sqrt{ }$ & $\sqrt{ }$ & $\sqrt{ }$ & $\sqrt{ }$ & Brazil & 100 & $\begin{array}{l}\text { China, Germany, } \\
\text { Canada, Austria }\end{array}$ \\
\hline 21 & Phosphorus & $\sqrt{ }$ & & & $\sqrt{ }$ & $\begin{array}{c}\text { U.S., Morocco, } \\
\text { Western Sahara, China, } \\
\text { Russia }\end{array}$ & 100 & Vietnam, Japan, China \\
\hline 22 & $\begin{array}{l}\text { Platinum- } \\
\text { group } \\
\text { elements }\end{array}$ & $\sqrt{ }$ & $\sqrt{ }$ & $\sqrt{ }$ & $\sqrt{ }$ & South Africa, Russia & 100 & NA \\
\hline 23 & $\begin{array}{l}\text { Rare-earth } \\
\text { elements }\end{array}$ & $\sqrt{ }$ & $\sqrt{ }$ & $\sqrt{ }$ & $\sqrt{ }$ & China, Australia & 100 & $\begin{array}{c}\text { China, Japan, France, } \\
\text { Taiwan }\end{array}$ \\
\hline 24 & Rhenium & & $\sqrt{ }$ & $\sqrt{ }$ & $\sqrt{ }$ & China, Poland, U.S. & NA & $\begin{array}{l}\text { China, U.K., U.S., } \\
\text { Singapore }\end{array}$ \\
\hline 25 & Selenium & & & & & Japan, Canada, U.S. & NA & Japan, Germany, China \\
\hline 26 & Silicon & $\sqrt{ }$ & & & & $\begin{array}{l}\text { China, Russia, } \\
\text { Norway, U.S. }\end{array}$ & NA & China, Australia, Japan \\
\hline 27 & Strontium & $\sqrt{ }$ & $\sqrt{ }$ & & $\sqrt{ }$ & $\begin{array}{l}\text { Spain, Mexico, China, } \\
\text { Iran }\end{array}$ & 100 & $\begin{array}{l}\text { Germany, Mexico, } \\
\text { Spain }\end{array}$ \\
\hline 28 & Tantalum & $\sqrt{ }$ & $\sqrt{ }$ & $\sqrt{ }$ & $\sqrt{ }$ & DRC, Rwanda, Nigeria & NA & U.S., Japan, China \\
\hline $\begin{array}{l}29 \\
30\end{array}$ & $\begin{array}{l}\text { Tellurium } \\
\text { Thallium }\end{array}$ & & $\sqrt{ }$ & & & China, Japan, Russia & NA & $\begin{array}{l}\text { Japan, China, Canada } \\
\text { Japan, China, U.S. }\end{array}$ \\
\hline 31 & Titanium & $\sqrt{ }$ & $\sqrt{ }$ & $\sqrt{ }$ & $\sqrt{ }$ & $\begin{array}{l}\text { South Africa, China, } \\
\text { Canada, Australia }\end{array}$ & NA & Japan, China, U.S. \\
\hline 32 & Tin & & $\sqrt{ }$ & & $\sqrt{ }$ & $\begin{array}{c}\text { China, Indonesia, } \\
\text { Burma }\end{array}$ & NA & $\begin{array}{l}\text { Indonesia, Malaysia, } \\
\text { Japan, Thailand }\end{array}$ \\
\hline 33 & Tungsten & $\sqrt{ }$ & $\sqrt{ }$ & $\sqrt{ }$ & $\sqrt{ }$ & China & NA & China, Japan, Bolivia \\
\hline 34 & Vanadium & $\sqrt{ }$ & $\sqrt{ }$ & $\sqrt{ }$ & $\sqrt{ }$ & $\begin{array}{c}\text { China, Russia, South } \\
\text { Africa }\end{array}$ & 100 & China, Brazil, Taiwan \\
\hline 35 & Zirconium & & $\sqrt{ }$ & $\sqrt{ }$ & $\sqrt{ }$ & $\begin{array}{l}\text { Australia, South } \\
\text { Africa, China }\end{array}$ & 100 & $\begin{array}{l}\text { U.S., Japan, South } \\
\text { Africa }\end{array}$ \\
\hline
\end{tabular}

Sources: Korea Institute of Geoscience and Mineral Resources (KIGAM), Korea Resources Corporation (KORES), U.S. Geological Survey (USGS). Note: NA: Not available, DRC: Democratic Republic of Congo.

Compared to the EU, the United States, and Australia, Korea has not established an official list of critical raw materials or critical minerals at the national level. However, Korea classifies minerals as legal, strategic, or rare metals. Specifically, the Mining Industry Act, which is the legislation governing the mining industry, classifies 59 minerals as legal for exploration and extraction purposes. At the national level, Korea set six strategic minerals: bituminous coal, uranium, iron ore, copper, zinc, and nickel, and recently, rare earths and lithium have been added. The National Program on Overseas Resources Development publishes strategic minerals based on high national demand for industry and high import dependence. Strategic minerals play a substantial role in the development of the national economy and the security of the nation. In addition, Korea has state-run reserve management and stockpiling of critical raw materials at the national level. The Ministry of Trade, Industry, and Energy (MOTIE) is primarily responsible for Korea's mineral laws and policies. Under the MOTIE, the state-owned Korea Resources Corporation plays a central role in the practical implementation of the raw materials concepts and strategies of the government and is also the most important promoter of foreign investment in overseas resource development [6,27]. 
Rare metals have been called the "vitamins of industry," and they are becoming "the lifeline of industry" owing to their importance in the industry. However, there is no standardized definition for the term "rare metal," and there is no consensus as to which elements it pertains [28]. In Korea, rare metals are apparently defined as the metals that are rare in the earth crust and are difficult to extract from ore; demand for rare metals has been on the increase as ore-deposits and productions are located only in a handful of countries, and materials are at a risk of supply disruption due to the dependence on imports from a particular country [10,28,29]. In Korea, the term "rare metal" is often used to refer to 35 metals, including antimony, arsenic, barium, beryllium, bismuth, boron, cadmium, cesium, chromium, cobalt, gallium, germanium, hafnium, indium, lithium, magnesium, manganese, molybdenum, nickel, niobium, platinum-group elements (PGMs), phosphorus, rare earth elements (REEs), rhenium, selenium, silicon, strontium, tantalum, tellurium, thallium, titanium, tin, tungsten, vanadium, zirconium [10,29]. Among these metals, rare metals such as lithium, nickel, REEs, cobalt, and molybdenum are becoming critical minerals because of the high demand for the 4th industrial revolution [30]. Korea's REEs include 15 lanthanide series elements, as well as yttrium and scandium [10]. Table 2 shows that Korea's rare metals such as cobalt, gallium, lithium, magnesium, indium, niobium, REEs, PGMs, tungsten, and vanadium are commonly deemed critical by the EU, the United States, Australia, and Japan. In addition, it shows that China is a leading producer of 17 rare metals, and Korea is highly reliant on rare metals imports, primarily from China and Japan because they are a major producer or supplier and Korea has close geographical proximity.

Countries can consider the list of critical raw materials as a realistic tool for supporting their policy development when negotiating trade agreements, eliminating trade distortions, identifying investment needs, or guiding research and innovation on new mining technologies, substitution, or recycling for the circular economy. In this regard, developing their own specific list of critical raw materials or critical minerals could be an efficient way to reduce import dependency and strengthen the diversity and security of the supply of critical mineral raw materials $[23,30]$.

\section{Recent Developments of Korea's Circular Economy Law and Policy}

\subsection{The Framework Act on Resources Circulation}

Korea has been shifting progressively from a pure waste management approach in the mid-1980s to the 3Rs (reduce, reuse, and recycle) approach in the 1990s and, subsequently, to a circularity of resources approach in the 2000s. As waste becomes a valuable resource, Korea moves towards a sustainable resource-circulating society [31,32]. As Figure 1 shows, Korea has extensive waste legislation, and particularly, the Act on the Resource Circulation of Electrical and Electronic Equipment and Vehicles (EEEV Act) was the first legal instrument to contribute in advancing the circular economy. To develop as an efficient resource-circulating society, Korea enacted the FARC, along with subordinate laws for its enforcement.

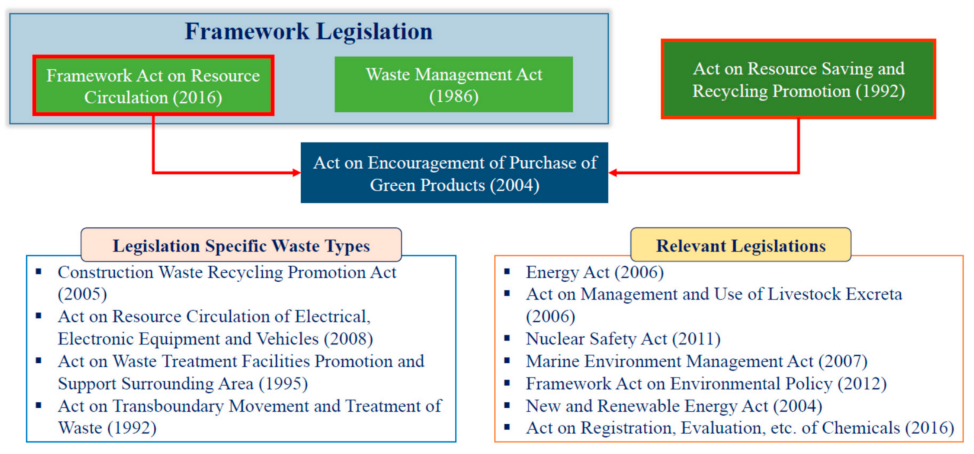

Figure 1. South Korea's Waste Legislation. 
The primary purpose of the FARC is to control waste generation with efficient use of resources and promote the circular use and proper disposal of waste, thereby minimizing natural resources and energy exploitation, preserving the environment, and achieving a sustainable resource-circulating society [33]. Through the FARC, Korea aims to shift from a pure waste management approach towards a new paradigm, emphasizing a resourcecirculating society [34].

The FARC defines crucial terms such as "resource-circulating society" and "circular resource." The term "circular resource" has been explicitly defined in the FARC as "among wastes, substances, or articles recognized by the Ministry of Environment pursuant to Article 9 other than wastes." The enforcement decree specifies the criteria for recognition of circular resources and methods for identifying circular resources. The Ministry of Environment retains the right to grant or refuse the circular resources recognition [33]. When waste turns into a valuable circular resource, then circular resources will no longer be subject to waste regulations due to the end-of-waste status. The term "resource-circulating society" is clearly defined as "a society in which its members minimize the use of natural resources by endeavoring together to reduce waste generation in their lives or industrial activities and use the generated wastes as raw materials or energy to the maximum extent possible." Here, "members" apparently include state, local governments, business entities, and citizens [33]. The definition of "resource-circulating society" addresses the role of waste-to-energy in the resource-circulating society but does not specifically elaborate on the FARC provisions.

The FARC establishes a waste hierarchy, allocates responsibilities to key actors, and requires setting quantitative targets and measures to support resource circulation, including waste disposal charges [33]. The FARC specifies the waste management prioritization based on the waste hierarchy: the minimization of waste generation through efficient use of resources, circular use of waste, and disposal of the generated waste according to the priority order of reuse, reclamation, energy recovery from waste, and appropriate disposal. In the case of waste disposal, the environmental or human health impact and damage should be considered [33]. Specifically, the FARC reflects concerns over hazardous chemicals by stating that "the Ministry of Environment may assess hazards and circular utilization for any of the products that are: (1) suspected of being harmful to human health and the environment because they contain any substances, such as air pollutants or toxic chemicals, under specific laws, such as the Clean Air Conservation or Chemicals Control Acts; and (2) suspected of not being circularly used when they become wastes" [33].

The Ministry of Environment undertakes primary responsibility for the policy and legal framework for waste acts at the central level. Under the FARC, the Ministry of Environment can impose waste disposal charges on waste dischargers who dispose of waste through landfilling or incineration despite the possibility of circular use of waste. Moreover, the ministry can set concrete measures and quantitative targets, such as long and mid-term targets for waste reduction, terminal waste disposal rates, and rates of recycling and energy recovery from waste, to assess the progress and effectiveness of a resource-circulating society [33].

Notably, the FARC integrates other relevant acts and moves toward a resourcecirculating society. For example, regarding concerns over hazardous chemicals, the FARC has links with other environmental acts, such as the Clean Air Conservation Act and Chemicals Control Act. Regarding waste disposal charges, the FARC incorporates the Waste Management Act (1986) and Act on Promotion of the Saving and Recycling of Resources (1992). However, the FARC does not explicitly incorporate the EEEV Act with respect to recycling or recovery of raw materials. This act is particularly important because electric and electronic equipment often consist of numerous precious and rare metals, and the recycling of these raw materials can provide a significant economic opportunity [35]. In addition, improper recovery of electronic waste can cause the loss of valuable resources and significant environmental impacts because of the presence of hazardous materials [36]. Moreover, the FARC does not specifically address concrete actions, strategies, measures, 
and targets to achieve a resource-circulating society, and, they are specifically addressed in the Resource Circulation Plan. Evidently, the FARC focuses on improving waste management by clarifying the legal status between waste and circular resources and strengthening the waste hierarchy.

\subsection{First Master Plan on Resource Circulation (2018-2027)}

Korea published the Resource Circulation Plan to implement medium- and longterm policies towards a sustainable circular economy, where the role of waste-to-energy, renewable energy waste, and critical raw materials recovery are specifically addressed. The Resource Circulation Plan was proposed for a ten-year period from 2018 to 2027 under Article 11 of the FARC and covers the entire life cycle of a product, from production to consumption, waste management, and from waste to resources by reclamation [37].

Overall, at the production stage, the design of a product from the beginning of a product's life is considered the resource circulation. Products should be made easier to recycle (e.g., packaging, electric, and electronic products). To promote eco-efficient resource consumption, single-use plastic bags should be banned, the use of unnecessary packaging should be minimized, and the increasing amount of per capita waste generated should be reduced. Regarding waste management, the innovation of the waste disposal, collection, and sorting system and zero direct landfills need to be established to promote recycling. In addition, waste treatment facilities should be improved. The reclamation stage particularly emphasizes the recycling of renewable energy wastes including modules, batteries, and solar photovoltaic (PV). These renewable energy wastes are considered a high value-added industry for the future, and the recovery of strategic rare metals, including lithium, titanium, tantalum, and REEs is important, because Korea is heavily dependent on imports for metals (99\%) and rare earth metals (approximately 100\%) [38]. With respect to electrical and electronic equipment and vehicles waste, Korea will strengthen extended producer responsibility programs by gradually enlarging the scope of the extended producer responsibility items. Several measures and systems have been adopted to promote recovery and technology development and resource recycling. Korea aims to raise the recycling target amount of electrical and electronic products per capita to the EU level (6.0 $\mathrm{kg} \rightarrow 8.0-8.8 \mathrm{~kg}$ ) [38].

Through the Resource Circulation Plan, Korea recognizes the importance of efficient waste-to-energy and the use of renewable energy sources to move towards a zero-waste society, particularly at the reclamation stage. Specifically, "zero waste" is defined by the Zero Waste International Alliance as "the conservation of all resources by means of responsible production, consumption, reuse, and recovery of products, packaging, and materials without burning and with no discharges to land, water, or air that threaten the environment or human health" [39]. "Zero waste" supports waste prevention, reuse, and recycling. Within this context, it appears that waste-to-energy directly contradicts with "zero waste," which is the diversion of waste from incineration and landfill [40]. Nevertheless, it may not be possible and practical for Korea to restrict the application of waste-to-energy under current circumstances. Because Korea is a relatively small and low-resource country heavily dependent on raw material imports, it is increasingly difficult to find landfill sites. The Resource Circulation Plan suggests that Korea will improve environmental safety and consider public acceptance for solid refuse fuel (SRF). It specifies that waste-to-energy will be implemented to maximize the circular economy's contribution in reducing greenhouse gas emissions and increasing energy from waste-to-energy operation. Waste-to-energy and bioenergy are important sources of renewable energy, contributing $67 \%$ and $24.9 \%$, respectively, in 2014 [41,42]. Waste-to-energy consists of waste gas, industrial waste, living waste, SRF, cement kiln fuel, and refinery fuel oil, whereas bioresources consist of biogas, wood chips, wood pellets, black liquor, sewage solid fuel, and bio-SRF [42]. Recently, Korea amended the Renewable Energy Act to provide a clearer definition of renewable energy, which came into effect in October 2019. It clarifies the bioenergy scope and excludes nonrenewable waste, such as SRF, from renewable energy resources [43]. SRF was considered 
the most viable solution for renewable energy sources for a long time but now turned into polluters that threaten public health by emitting pollutants in the process of converting waste to energy.

Furthermore, the Resource Circulation Plan sets concrete measures, medium and longterm policy objectives, and directions for matters concerning to efficiently use resources, to reduce waste generation, and facilitate circular utilization. It specifically sets targets for the reduction of waste generation to $20 \%$, circular utilization rates from $70.3 \%$ to $82 \%$ by recycling packaging waste and electronic waste, terminal waste disposal rates from $9.1 \%$ to $3.0 \%$, and energy recovery rates from $16.3 \%$ to $20.3 \%$ by biogas [38]. Throughout the Resource Circulation Plan, Korea acknowledges the trend changes, such as consumption patterns due to improved living standards, highly energy-intensive industry, energy transition from fossil fuels to renewable energy, increasing electronic waste generation due to the 4th industrial revolution, strengthened regulation for waste and harmful materials, and high competition for critical raw materials.

\section{Towards Achieving Greater Resource Security: The Master Plan on Resource Development (2020-2029)}

There is no valid comprehensive Korean resource law or raw materials law to cover diverse resource policies, including domestic and overseas resource development, resource security, stockpiling, and efficient resource management. Resource security has always been important but is now becoming a leading rationale for Korea's resource policy, and the formulation of a resource security law is critical concerning its resource security strategy. The existing Framework Act on Low Carbon and Green Growth and Energy Act primarily focus on climate change, energy security, and energy transition in a low-carbon fashion by emphasizing energy efficiency, reducing greenhouse gas emissions, and increasing the renewable energy share. They emphasize the efficient use of energy resources rather than the security of supply of critical raw materials and minerals.

Over the last decades, Korea's resource policy has focused on exploration, production, and development of overseas resources. State-owned and state-controlled enterprises such as the Korea National Oil Corporation (KNOC), Korea Gas Corporation (KOGAS), and Korea Resources Corporation (KORES) have played a central role in the practical implementation of the Korean government's overseas resource policies and strategies [6]. The National Program on Overseas Resource Development was formulated for a ten-year period every three years. Since the establishment of the first national program on overseas resource development in 2001, it has emphasized oil, gas, and eight strategic minerals (bituminous coal, uranium, iron ore, copper, zinc, nickel, rare earths, and lithium) and their self-sufficiency rate and projections [44].

Korea currently sets up a comprehensive resource policy, and the security of the supply of critical raw materials has become a high priority due to its high import dependence. Resource security has become a new paradigm for Korea's resource policy. The Resource Development Plan combines the 6th National Program on Overseas Resource Development with the 3rd National Program on Submarine Mineral Resource Development to establish a comprehensive domestic and overseas resource development plan. Through the Resource Development Plan, Korea has made efforts to reinforce its resource security to respond to the changes in the international resources market and domestic industrial environment. The Resources Development Plan aims to develop a solid resource security that supports the national economy. The main driving strategies include revitalizing the resources development industry, proactive responses to the changes in the energy and resources environment, and policy shift from resource development to resource security [30].

Notably, the focus of the Resource Development Plan shifts from securing strategic minerals to securing critical minerals for new industry demands. Under this plan, the list of "critical minerals" and comprehensive roadmap for stockpiling of critical minerals will be established. Overseas resource development will focus on stable access to critical minerals, such as lithium, cobalt, and REEs [30,45]. Further, the Plan acknowledges the importance of recycling raw materials for sustainable raw material security. In this regard, Korea will 
expand domestic urban mining and create an infrastructure to establish overseas urban mining [30].

Regarding a policy shift from resource development to resource security, Korea will establish a comprehensive system and process to check the national resource security situation. Specifically, it will develop "National Resource Security Indicators" considering various factors encompassing resource development, stockpiling, infrastructure, and transportation. Moreover, it will propose an action plan for the mid- to long-term resource security roadmap and formulate the "Resource security Act" (tentative). In line with the energy transition and the 4th industrial revolution, a resource strategy for securing stable critical raw materials and minerals will be established based on the potential demand for raw materials and minerals. Strategies include encouraging private entities to invest in overseas resource development, enlarging direct imports for domestic use by providing incentives, and expanding the stockpiling of critical minerals to meet new industry demands [30].

Nevertheless, the Resource Development Plan has certain limitations. The plan does not sufficiently emphasize the importance of strategic minerals and concrete resource development strategies and targets. Critical energy resources and non-energy raw materials should receive full attention in the plan. In addition, the possibility of resuming domestic resource development of critical raw materials is not illustrated. In this regard, the Mining Industry Act should be integrated with the "Resource Security Act" to cover domestic resource developments.

\section{Renewable Energy and Critical Raw Materials}

The management of renewable energy waste and recovery of raw materials play a key role in the circular economy and resource security. Solar PV, wind power, and hydrogen power are on the verge of rapid expansion, particularly due to the current "Renewable Energy 3020 Plan" to increase the renewable energy share in the power sector to $20 \%$ by 2030. Furthermore, the Korean government has announced a draft of Korea's Third Energy Master Plan, which proposes to expand the share of renewable energy sources, especially solar, wind, and hydrogen power, to $30-35 \%$ by 2040 [46]. Accordingly, several types of renewable energy wastes, including solar PV and wind turbines, are expected to grow in the coming years.

Until recently, Korea has not established any measures, systems, or legal instruments to address the recycling of anticipated waste, including solar PV, wind turbines, and electric vehicle batteries. Solar PV waste was classified as industrial waste; PV module operation was not monitored, and the generation of waste from past PV installations was not calculated [47]. In this regard, the Korean government proposed to amend the Enforcement Decree to the EEEV Act by classifying solar PV panels as an extended producer responsibility (EPR) item, making solar panel manufacturers and importers responsible for collection and recycling [48]. Under the Enforcement Decree to EEEV Act, the EPR target items had been expanded from 10 to 27 items and recently proposed to enlarge the scope of EPR items to 50 items. Similarly, the amended EU directive on electrical and electronic equipment waste (WEEE Directive 2012/19 EU) enlarged the scope to include photovoltaic panels to Annex II category 4. EU PV companies have become responsible for the proper collection, reuse, or recycling and disposal of PV modules they sell. However, the EU WEEE Directive did not include the wind turbines in the amendments but made proposals to limit the discarding of wind turbine blades in landfills [49].

Critical raw materials, which are often in electronic devices, are a central element in the circular economy package and are ideal candidates for a circular economy. Critical raw materials are intrinsically linked to all industries across all supply chain stages, particularly for high-tech products and emerging innovations-technological progress [50]. Compared to fossil fuels or food, they are not consumed, eternally recyclable, and they do not lose their intrinsic properties during recycling [36]. In particular, renewable energy technologies, such as wind and solar PV energy, rely on various critical raw materials. Currently, two 
types of solar PVs are used: crystalline silicon and thin-film [51]. Due to the toxicity of cadmium, Korea mainly uses crystalline silicon, which has a market share of approximately $90 \%$ [51]. Furthermore, solar panel manufacturers use silicon metal, a raw material, to manufacture polysilicon. Polysilicon is the core material of solar panels, and Korea is highly dependent on China to secure $80 \%$ of silicon metal [52]. Unlike the EU, Korea does not classify silicon metal as a rare metal even if there is a high supply risk due to heavy import dependence. In contrast, the EU uses thin-film solar cells consisting of two types: cadmium telluride and copper indium gallium selenide. EU solar PV manufacturers use critical raw materials such as tellurium, gallium, and indium to produce thin-film solar cells. The EU's dependency on China for indium and gallium is very high, at $58 \%$ and $69 \%$, respectively [53]. The EU includes indium and gallium in the list of critical raw materials.

Regarding wind power, there are two types of offshore wind energy technologies: hybrid systems that combine a gearbox with permanent magnets and direct-drive technologies that eliminate the gearbox. To produce permanent magnets for the generators, the rare earths neodymium and dysprosium are used [53]. China is a dominant producer of neodymium and dysprosium, and the wind industry is heavily reliant on China [53]. As the demand for these materials is expected to rise, there are efforts to develop alternative technologies that use less neodymium and dysprosium, replace permanent magnets or reclaim neodymium and dysprosium [53]. Although several critical raw materials have high technical and real economic recycling potential and there is encouragement from governments to move towards a circular economy, the recycling input rate of these materials is generally low because of the complexity of recycling. Developing a specific policy for the eco-design of wind turbines for easier recycling and innovative actions for efficient use of these materials in wind and PV energy technologies are required for future action [50].

\section{Conclusions}

This study analyzed Korea's current policy on the circular economy and resource security and recognized the importance of managing critical raw materials and minerals for its continuous economic growth. It was observed that circular economy and resource security should not be treated as distinct areas, and, instead, both concepts should be considered together to manage critical raw materials and minerals. Securing a stable and sustainable supply of critical raw materials is crucial for resource security. The recycling and recovery of critical raw materials from waste streams, particularly electronic devices, batteries, and end-of-life products, are efficient means for securing them, thereby strengthening resource security using secondary raw materials for Korea, which is heavily dependent on imports for minerals and rare earths. The COVID-19 crisis gave countries a comprehensible lesson to reduce dependency and strengthen diversity and security of supply of raw materials. A transition towards circular economy and resource security would ultimately contribute to the development of a sustainable, low-carbon, resource-efficient, and competitive economy.

To this end, Korea's new resource policy should comprehensively incorporate circular economy into resource security policy. Furthermore, the current term "rare metal" and its definition should be clearly redefined and modernized. In drafting the official list of critical minerals, Korea's specific circumstances, such as economic, geological, technological, geopolitical, environmental, and social factors to determine criticality should be considered, and the list should be assessed and updated regularly to reflect the changing circumstances. A monitoring system covering the entire lifecycle of critical minerals, together with the list of critical minerals, should be established to assess the progress and identify success factors. To facilitate the transition to an improved circular economy and resource security, the EPR scope should be expanded to cover estimated wastes for the efficient management of critical raw materials. Resource security policy measures should include consistent and uniform stockpiling as a short-term strategy and domestic and overseas resource development as a long-term strategy. In parallel with these strategies, Korea should promote the diversification of suppliers and the supply chain of critical minerals outside China and Japan to reduce its exposure to supply risks. 
Furthermore, a tentative Korean resource security law should acknowledge the resource efficiency and sustainable supply of raw materials and metals. It should consolidate the global market for raw materials and minerals, domestic and overseas development, urban mining (e.g., recycling and recovery of critical raw materials), and national security through stockpiling reserves and enhancing economic cooperation with North Korea. The Resources Circulation Plan and Resource Development Plan clearly demonstrate that Korea has proactively undertaken substantial steps and strategies to prepare for future challenges in the areas of critical raw materials or critical minerals.

Author Contributions: K.L. designed the research framework, collected the data, and wrote the original draft. J.C. offered critical comments and participated in revising. All authors have read and agreed to the published version of the manuscript.

Funding: This work was supported by the Dong-A University research fund.

Conflicts of Interest: The authors declare no conflict of interest.

\section{References}

1. Korhonen, J.; Nuur, C.; Feldmann, A.; Birkie, S.E. Circular economy as an essentially contested concept. J. Clean. Prod. 2018, 175, 544-552. [CrossRef]

2. Hayes, S.M.; MaCullough, E.A. Critical minerals: A review of elemental trends in comprehensive criticality studies. Resour. Policy 2018, 59, 192-199. [CrossRef]

3. Mancini, L.; Benini, L.; Sala, S. Characterization of raw materials based on supply risk indicators for Europe. Int. J. Life Cycle Assess. 2018, 23, 726-738. [CrossRef]

4. Stuermer, M. International Raw Materials Boom. A Challenge for Multilateral Trade Policy. Int. Politics Soc. 2008, 2, 126-139.

5. U.S. Energy Information Administration. Country Analysis Brief: South Korea. 2018. Available online: https://www.eia.gov/ international/content/analysis/countries_long/South_Korea/south_korea.pdf (accessed on 27 October 2020).

6. Kim, J. The Formulation of Korea's Resource Policy: Resource Diplomacy, Public-Private Consortium and International Agreements. Asian J. WTO Int. Health Law Policy 2014, 9, 287-329.

7. Hong, J.H.; Kim, J.; Son, W.; Shin, H.; Kim, N.; Lee, W.K.; Kim, J. Long-term energy strategy scenarios for South Korea: Transition to a sustainable energy system. Energy Policy 2019, 127, 425-437. [CrossRef]

8. Noh, C.; Kim, I.; Jang, W.; Kim, C. Recent Trends in Renewable Energy Resources for Power Generation in the Republic of Korea. Resources 2015, 4, 751-764. [CrossRef]

9. Kim, H.T. Digital Transformation Trends of the Energy and Mineral Resources Development Industries in the Era of the Fourth Industrial Revolution. J. Korean Soc. Miner. Energy Resour. Eng. 2019, 56, 514-528. (In Korean) [CrossRef]

10. Kim, K.-H. Trends in Rare Metals Trade and Implications; Trade Focus; Institute for International Trade: Seoul, Korea, 2018. (In Korean)

11. Hilpert, H.G.; Mildner, S.-A. Fragmentation or Cooperation in Global Resource Governance? A Comparative Analysis of the Raw Materials Strategies of the G20; SWP Research Paper: Berlin, Germany, 2013; pp. 131-136.

12. Claxton, J.M.; Nottage, L.; Williams, B. Litigating, Arbitrating and Mediating Japan-Korea Trade and Investment Tensions. J. World Trade 2020, 54, 591-614.

13. Jeon, H.-S.; Baek, S.-H.; Kim, S.-M.; Go, B.-H. Status of Reserves and Development Technology of Rare Earth Metals in Korea. J. Korean Soc. Miner. Energy Resour. Eng. 2018, 55, 67-84. (In Korean) [CrossRef]

14. Chung, W.J. Mineral Resource Industry of North Korea and Two Korea's Cooperation. J. Korean Soc. Miner. Energy Resour. Eng. 2019, 56, 204-211. (In Korean) [CrossRef]

15. Mancheri, N.A.; Sprecher, B.; Bailey, G.; Ge, J.; Tukker, A. Effect of Chinese policies on rare earth supply chain resilience. Resour. Conserv. Recycl. 2019, 142, 101-112. [CrossRef]

16. Chen, Y.; Zheng, B. What Happens after the Rare Earth Crisis: A Systematic Literature Review. Sustainability 2019, 11, 1288. [CrossRef]

17. Switzer, S.; Gerber, L.; Sindico, F. Access to Minerals: WTO Export Restrictions and Climate Change Considerations. Laws 2015, 4, 617-637. [CrossRef]

18. Dooley, B.; Choe, S.-H. Japan Imposes Broad New Trade Restrictions on South Korea. The New York Times. 1 August 2019. Available online: https://www.nytimes.com/2019/08/01/business/japan-south-korea-trade.html (accessed on 18 October 2020).

19. Yamazaki, M.; Yang, H.; Park, J. The High-Tech Trade Dispute Rooted in Japan's Wartime History; Reuters: Tokyo, Japan; Seoul, Korea, 8 June 2019; Available online: https:/ / www.reuters.com/article/us-southkorea-japan-laborers-explainer-idUSKCN1U31D1 (accessed on 18 October 2020).

20. Goodman, S.; VerWey, J.; Kim, D. The South Korea-Japan Trade Dispute in Context: Semiconductor Manufacturing, Chemicals, and Concentrated Supply Chains; United States International Trade Commission: Washington, DC, USA, 2019. [CrossRef] 
21. Request for Consultations by the Republic of Korea, Japan-Measures Related to the Exportation of Products and Technology to Korea. WT/DS590/1. 2019. Available online: https://docs.wto.org/dol2fe/Pages/SS/directdoc.aspx?filename=q:/WT/DS/ 590-4.pdf\&Open=True (accessed on 22 December 2020).

22. Barteková, E.; Kemp, R. National strategies for securing a stable supply of rare earths in different world regions. Resour. Policy 2016, 49, 153-164. [CrossRef]

23. European Commission. Critical Raw Materials Resilience: Charting a Path towards Greater Security and Sustainability; COM (2020) 474 Final; European Commission: Brussels, Belgium, 2020.

24. Humphries, M. Critical Minerals and US Public Policy; Congressional Research Service: Washington, DC, USA, 2019.

25. Nassar, N.T.; Brainard, J.; Gulley, A.; Manley, R.; Matos, G.; Lederer, G.; Bird, L.R.; Pineault, D.; Alonso, E.; Gambogi, J.; et al. Evaluating the mineral commodity supply risk of the U.S. manufacturing sector. Sci. Adv. 2020, 6. [CrossRef]

26. Australian Government. Australia's Critical Minerals Strategy; Australian Government: Canberra, Australia, 2019.

27. Chung, J. The Mineral Industry of the Republic of Korea; USGS 2016 Minerals Yearbook Republic of Korea; US Geological Survey: Washington, DC, USA, 2019.

28. Lee, M. International Cooperation to Development of Strategy and RED Collaboration for Substitution of Rare Earth Resources; US Department of Energy: Washington, DC, USA, 2014.

29. Korea Institute for Rare Metals (KIRAM). Available online: https://www.kiram.re.kr/web/ko/page/page02_01_01.php (accessed on 27 September 2020).

30. The Ministry of Trade, Industry and Energy (MOTIE). The Master Plan on Resource Development; MOTIE: Sejong, Korea, 2020. (In Korean)

31. Lee, K.; Cha, J. Recent developments in Korea's Framework Act on Resource Circulation: Toward a resource-circulating society. J. Mater. Cycles Waste Manag. 2018, 20, 1986-1998. [CrossRef]

32. OECD. OECD Environmental Performance Reviews: Korea; OECD Publishing: Paris, France, 2017. [CrossRef]

33. The Ministry of Environment (MOE). Framework Act on Resource Circulation; MOE: Sejong, Korea, 2016. (In Korean)

34. The Ministry of Environment (MOE). White Paper of Environment; MOE: Sejong, Korea, 2016. (In Korean)

35. Lee, C.H.; Bae, W. A Comparative Study on the Waste Electrical and Electronic Equipment (WEEE) Recycling Policies of the European Union and the Republic of Korea. Environ. Policy 2015, 23, 43-68. (In Korean) [CrossRef]

36. Hagelüken, C.; Lee-Shin, J.U.; Carpentier, A.; Heron, C. The EU Circular Economy and Its Relevance to Metal Recycling. Recycling 2016, 1, 242-253. [CrossRef]

37. Herrador, M.; Cho, Y.; Park, P. Latest circular economy policy and direction in the Republic of Korea: Room for enhancements. J. Clean. Prod. 2020, 269. [CrossRef]

38. The Ministry of Environment (MOE). The First Master Plan on Resource Circulation; MOE: Sejong, Korea, 2018. (In Korean)

39. Zero Waste International Alliance (ZWIA). Zero Waste Definition; ZWIA, 2018. Available online: http:/ / zwia.org/zero-wastedefinition/ (accessed on 9 December 2020).

40. Zaman, A.U. A Strategic Framework for Working toward Zero Waste Societies Based on Perceptions Surveys. Recycling $2017,2,1$. [CrossRef]

41. Alsharif, M.; Kim, J.; Kim, J.H. Opportunities and Challenges of Solar and Wind Energy in South Korea: A Review. Sustainability 2018, 10, 1822. [CrossRef]

42. Oh, D.; Kim, S.H. Green Finance in the Republic of Korea: Barriers and Solutions; ADBI Working Paper 897; Asian Development Bank Institute: Tokyo, Japan, 2018.

43. Cho, S. Nonrenewable Waste Is Excluded from Renewable Energy. Korea Energy. 7 January 2019. Available online: http://www. koenergy.co.kr/news/articleView.html?idxno=104243 (accessed on 27 October 2020).

44. The Ministry of Trade, Industry and Energy (MOTIE). The Fifth National Program on Overseas Resource Development; MOTIE: Sejong, Korea, 2014. (In Korean)

45. Kim, D.; Kim, Y. Implications of the 6th National Program for Overseas Resources Development. J. Korean Soc. Miner. Energy Resour. Eng. 2020, 57, 392-397. (In Korean) [CrossRef]

46. Korea Times. Shift to Renewable Energy: Master Plan Calls for Drastic Expansion of Solar. Wind Power. 21 April 2019. Available online: http:/ / www.koreatimes.co.kr/www / opinon/2019/04/202_267538.html (accessed on 27 October 2020).

47. Kim, H.; Park, H. PV Waste Management at the Crossroads of Circular Economy and Energy Transition: The Case of South Korea. Sustainability 2018, 10, 3565. [CrossRef]

48. Lee, K.; Cha, J. Management of Solar Photovoltaic Panels under the Extended Producer Responsibility Legislation. J. Korean Soc. Miner. Energy Resour. Eng. 2019, 56, 367-376. (In Korean) [CrossRef]

49. Lesniewska, F. Renewable energy, waste management and the circular economy in the EU: Solar PV and wind power. In Research Handbook on EU Energy Law and Policy; Leal-Arcas, R., Wouters, J., Eds.; Edward Elgar Publishing: Cheltenham, UK, 2017; pp. $460-468$.

50. European Commission. Report on Critical Raw Materials and the Circular Economy; (CRM Report). SWD (2018) 36 Final; European Commission: Brussels, Belgium, 2018.

51. Månberger, A.; Stenqvist, B. Global metal flows in the renewable energy transition: Exploring the effects of substitutes, technological mix and development. Energy Policy 2018, 119, 226-241. [CrossRef] 
52. Kim, T.H.; Lee, T.E. Strategy to Secure Resources against Changing Demand in Materials in an Era of Energy Conversion; Korea Energy Economics Institute: Ulsan, Korea, 2018.

53. Rabe, W.; Kostka, G.; Stegen, K.S. China's supply of critical raw materials: Risks for Europe's solar and wind industries? Energy Policy 2017, 101, 692-699. [CrossRef] 